\title{
Jandira Lorenz: entre os desenhos e a docência
}

\author{
Helena Villas Garcia Vasconcelos
}


Baseada na história oral como técnica de pesquisa, procurei contribuir para a história do Centro de Artes (CEART) da Universidade do Estado de Santa Catarina (UDESC) entrevistando Jandira Lorenz, professora aposentada do Departamento de Artes Visuais. A entrevista foi realizada em um estúdio de arte vítrea na Lagoa da Conceição em Florianópolis. Na primeira parte do texto apresento a entrevistada e seu vínculo com a criação do CEART. Logo em seguida, discorro sobre a docência, onde a professora narra sobre a sua escolha pela profissão e a sua formação. Histórias sobre as disciplinas e a convivência com os colegas professores do CEART, também fazem parte desta narrativa. E para finalizar, trago o relato feito por Jandira sobre a representação do CEART na sua vida. Através do olhar desta professora é possível conhecer um pouco da história e fatos importantes que aconteceram dentro do Centro de Artes.

Palavras-chave: Professora; Artista; Educação Artística; CEART.

\section{Introdução}

Tandira Lorenz Bieszczad Neves, conhecida como Jandira Lorenz, foi professora do Departamento de Artes Visuais do Centro de Artes (CEART) da Universidade do Estado de Santa Catarina (UDESC). Trabalhou entre 1976 e 1996, quando teve a oportunidade de participar da formação de diversos professores de artes. Alguns professores que atualmente integram o corpo docente do Departamento de Artes Visuais foram alunos de Jandira e sugeriram seu nome para participar deste projeto sobre o resgate da história do CEART. Optei por utilizar a história oral que "tem como suporte as lembranças, evidenciando uma memória coletiva” (MARCONI; LAKATOS, 2010, p. 129). A história oral é uma técnica de pesquisa que procura através da entrevista resgatar fatos relevantes. A entrevista com Jandira Lorenz aconteceu em um estúdio de arte vítrea, localizado na Lagoa da Conceição em Florianópolis, onde Jandira estava auxiliando um trabalho de vitral. Esse vitral é uma encomenda de uma igreja de Curitibanos. Jandira fez o desenho e estava auxiliando seu colega na montagem. Eles me explicaram todo o processo de construção e montagem daquela peça. Apesar do barulho que havia no local durante a entrevista, foi 
gratificante observar aquele momento de confecção do vitral.

Jandira Lorenz iniciou seus estudos de graduação em Belas Artes, no Instituto de Artes da Universidade do Rio Grande do Sul (UFRGS), na cidade de Porto Alegre, porém teve que interromper o curso devido à mudança com a família para São Paulo. Chegando a São Paulo, buscou a continuação da sua formação acadêmica na Fundação Armando Alvares Penteado (FAAP), onde teve que fazer o curso completo de Artes de quatro anos, pois as disciplinas que havia cursado no Rio Grande do Sul não foram reconhecidas por divergências nos nomes. Jandira confirma: "Fiz seis anos de universidade". Continuou seus estudos de pós-graduação na Escola de Comunicação e Artes (ECA) da Universidade de São Paulo (USP). $\mathrm{Na}$ época em que terminou o seu mestrado foi convidada a cursar o doutorado, porém não aceitou, pois viria morar em Florianópolis. Sua dissertação ${ }^{1}$, sobre a obra da artista Eli Heil ${ }^{2}$, publicada em forma de livro $^{3}$ no ano de 1985 pela Fundação Catarinense de Cultura.

\section{Anos 70 e o curso de Educação Artística}

Como artista, Jandira possui uma grande produção na área do desenho. Nos anos 70 participou de exposiçôes com seus trabalhos e recebeu vários prêmios. O primeiro prêmio foi em 1975, em São Paulo, no 3o Salão da Editora Abril. Em 1976 participou da Mostra Nacional Arte Agora I, no Museu de Arte Moderna (MAM) do Rio de Janeiro. (BORTUCAN, 2012, p. 43). Veio a Florianópolis participar de uma exposição e encontrou com Dimas Rosa, professor do curso de Educação Artística da UDESC, que já conhecia Jandira.

O Curso de Educação Artística estava sendo ampliado devido à aprovação da Lei de Diretrizes e Bases 5.692 de 1971, que tornou obrigatória a disciplina de Educação Artística para os currículos do então $1^{\circ}$ e $2^{\circ}$ graus, hoje denominados ensino fundamental e ensino médio. Com essa obrigatoriedade fez-se necessário a formação de professores para a área. Segundo Penna (2012, p. 124), “em 1973, são aprovados o Parecer CFE no 1248/73 e a Resolução CFE no 23/73,

${ }^{1}$ LORENZ, Jandira. A obra plástica de Eli Heil. Dissertaçăo de Mestrado, São Paulo, 1981

${ }^{2}$ Pintora, desenhista, escultora e ceramista autoditada Catarinense. Conhecida por ter seu próprio museu, "O Mundo Ovo de Eli Heil". Para maiores informaçóes acessar: http://www.eliheil.org.br/

${ }^{3}$ LORENZ, Jandira. A obra plástica de Eli Heil. FCC Ediçốes, 1985. 
termos normativos acerca do curso de Licenciatura em Educaçáo Artística”. Assim se estabeleceu a Licenciatura de $1^{\circ}$ grau, também conhecida como Licenciatura curta, com duração de três anos que formava o professor para atuar de $5^{\mathrm{a}}$ à $8^{\mathrm{a}}$ série. A Licenciatura curta oferecia uma formação geral em Educação Artística, envolvendo Artes Plásticas, Artes Cênicas, Música e Desenho. Já a Licenciatura plena, com duração de mais dois anos, habilitava o professor para uma área específica, subdivididas na época em Artes Plásticas, Artes Cênicas, Música e Desenho.

É nesse cenário que se instala o Centro de Artes, com a criação em 1973 do Curso de Educação Artística, na Faculdade de Educação (FAED). (KUERTEN, 2005). Jandira conta que esse curso funcionava inicialmente no centro de Florianópolis, na Rua Saldanha Marinho, passando depois para a Praça Getúlio Vargas, e, no ano de 1985, suas instalaçóes foram para o bairro do Itacorubi, onde se encontra no momento.

Para a ampliação do curso de Educação Artística era necessária a contratação de professores e, por tal motivo o professor Dimas Rosa convida Jandira para assumir algumas disciplinas no curso. O professor Dimas sabia que Jandira tinha interesse em vir para Florianópolis, que naquele momento estava residindo em São Paulo, onde trabalhava na Editora Abril como assistente de Arte na Revista Exame e na Revista POP, "que nâo existe mais, mas que o pessoal da minha época se lembra”. Depois da conversa durante a exposição, o professor Dimas "mandou um telegrama, que naquela época era a época dos telegramas, não tinha e-mail" avisando que havia duas disciplinas que ela poderia assumir. "Aí conferenciei com meu marido e ele disse assim: vamos". Em 1976, Jandira assume as aulas de História da Arte e Fundamentos da Linguagem Visual.

A professora Jandira foi a primeira chefe de departamento do curso de Educação Artística. Sorrindo, Jandira comenta: "é um fato altamente histórico, no qual eu não fiz praticamente nada" porque na época era apenas uma "familiazinha de uns 15 professores", que trabalhavam onde hoje é o Museu da Escola Catarinense, na Rua Saldanha Marinho, no centro de Florianópolis, depois, o curso foi para outro prédio na Praça Getúlio Vargas e foi nesse local, também conhecido por Praça dos Bombeiros, que Jandira assumiu a chefia do curso. Ela lembra de alguns nomes dos professores daquela época, 
tais como: "Nancy Batistoti, professora de Música, a professora de Teatro Dilza Délia Dutra, Delci Canela de Pintura, Geraldo Bassi, que também trabalhava muito com gravuras, Dimas Rosa, Milton Valente de Desenho Técnico, Jorge Carvalho, a professora Dora, entre outros".

Jandira conta que passou por todos os processos de transformaçóes e mudanças dos prédios e dos currículos dos cursos do departamento de Artes Visuais da UDESC. No início, estavam instalados no centro, em dois locais diferentes, já mencionados anteriormente. Depois foram para "as casinhas de madeira" no bairro do Itacorubi, onde Jandira teve a oportunidade de trabalhar quando eram "novinhas". Ela detalha que essas casas tinham um "clima japonês, [...] com cheirinho de tinta". Participou também das transformaçóes curriculares, quando o curso foi separado em Bacharelado e Licenciatura e, consequentemente, da reformulação dos programas.

\section{A docência para Jandira}

A admiração pela docência veio desde a infância. Jandira é filha e muita satisfação dentro da sua família. Ser professor, na família de Jandira, sempre foi uma condição de passar informaçóes e valores. Enquanto Jandira falava sobre a sua escolha por ser professora, e que esta escolha estava ligada ao modo de ser da sua família e o desejo de transmitir seus conhecimentos, lembrei das palavras de Nóvoa (2009, p.15), que diz que "o professor é a pessoa, e que a pessoa é o professor. Que é impossível separar as dimensóes pessoais e profissionais. Que ensinamos aquilo que somos e que, naquilo que somos, se encontra muito daquilo que ensinamos"

Jandira vivenciou na sua família essa transmissão de valores. Conta que seu pai e seu avô eram mestre-escola, como era chamado o "professor de instrução primária" (BUENO, 1996, p. 428). Seu pai dava aula bilíngue, falava em Português e Polonês, na escola primária da colônia de poloneses imigrantes recém chegados ao Brasil. $\mathrm{Na}$ hora do recreio seu pai tocava violino para os alunos, que dançavam e cantavam. Jandira sempre teve admiração pela tarefa de ser professor, como se pode observar quando ela comenta:

Eu sempre achei lindo que meu pai ensinava as coisas mais 
simples, assim como exemplo, entrar na escola limpa, o tamanquinho, era tamanquinho que eles usavam - e limpavam - o tamanquinho, tudo era assim, formando um ser humano mais sensível [...] Meu avô também era professor de primário, e este convívio mais humanístico, sempre me fascinou.

A professora também sempre prezou pela formação do ser humano, a formação de um ser sensível, e através da docência, além dos conteúdos sobre a História da Arte, o Desenho e Artes Plásticas, pôde trabalhar essas questóes com seus alunos, mesmo sendo alunos de nível universitário. Ela afirma que:

Sempre quando eu dava aula, também gostava de fazer com que os alunos se dessem conta de que além de estar estudando o Desenho, Pintura ou coisas associadas a Artes Plásticas, que uma pessoa sensível pra Arte deve ser sensível pro mundo e todas as formas de Arte, música, teatro, poesia, literatura, dança e gostava assim de mexer também com estes assuntos para as pessoas não ficarem tão compartimentadas.

Jandira faz um relato de uma turma que a deixou muito emocionada. O semestre já estava terminando, quando os alunos descobriram que ela náo seria mais professora deles e, então, conversaram e decidiram que todos reprovariam na disciplina para continuar a ter mais um semestre de aula com ela. Apesar de ter ficado muito emocionada com o desejo dos alunos, pela valorização de seu trabalho, Jandira não permitiu que tomassem tal atitude, pois todos estavam prestes a concluir o curso.

Ainda sobre a questáo de ter gostado de ser professora, Jandira afirma se orgulhar muito de seus ex-alunos. Fica entusiasmada em saber que eles estão fazendo trabalhos maravilhosos. Conta que recebeu um livro de uma amiga e, para sua surpresa, um dos capítulos do livro foi escrito por uma ex-aluna sua. Ao ler sobre a autora percebeu que ela havia feito vários cursos voltados para a área de artes plásticas depois de ter se formado pela UDESC. Outros ex-alunos trabalham como artistas, em fundações, ou escrevendo e pesquisando sobre arte. Jandira se orgulha e considera que a "sementinha gerou uma plantinha, que por sua vez, [...] estão rendendo frutos, e a gente continua nos alunos". 


\section{A carreira docente no CEART}

$\mathrm{D}$ urante o período que esteve lecionando no Centro de Artes Jandira assumiu várias disciplinas: História da Arte I, II, III, IV e V, Fundamentos da Linguagem Visual I e II, Evolução das Artes Visuais I e II, Gravura, Xilogravura, Representaçóes Gráficas, e a mais importante Desenho I, II, III, IV e V.

Iniciou seu trabalho como professora lecionando a disciplina de História da Arte. Afirma que foi muito importante ter ministrado essa disciplina pelo fato de ter que aprofundar seus conhecimentos sobre a História da Arte, e comenta: "quando eu comecei a lecionar eu era uma recém formada. A gente náo imagina que tem todo aquele conhecimento na cabecinha, só porque estudou. Quando eu tive que retomar, pra mim foi maravilhoso no sentido de que eu aprendi muito mais."

Sobre as aulas de História da Arte, Jandira lembra a dificuldade em conseguir livros e materias sobre arte. Conta que seu pai trabalhava em uma editora de São Paulo e por intermédio dele conseguia alguns livros, porém a maioria deles era disponibilizado apenas em francês, inglês, italiano ou alemáo, pois havia pouco material em português. Ela usava slides nas aulas, mas pensando em todo o material disponível hoje em dia, diz que poderia planejar aulas "magníficas".

Em determinada época, a professora estava envolvida apenas com disciplinas teóricas e começou a ter problemas vocais. Em uma reunião, onde os colegas estavam "distribuindo a disciplina de Desenho, como quem está rifando aula de desenho", ela pensou "o quê, eu sou desenhista, eu vou pegar Desenho". Valorizava muito essa disciplina, como se pode perceber no seguinte comentário: "todo mundo pensa que pegar desenho é fácil, porque manda o aluninho desenhar. Mentira! O Desenho é muito, muito, muito complexo”. Nas aulas de Desenho, a professora diz que conseguia somar os conhecimentos, no sentido que uma disciplina alimentava a outra. Ela teve a oportunidade de fazer isso, pois lecionava diversas disciplinas, tanto teóricas quanto práticas.

Nas aulas de Desenho, a professora conta que muitas vezes ela e os alunos acabavam não desenhando efetivamente durante a aula, mas passavam o tempo todo falando sobre desenho. Os alunos traziam desenhos que faziam fora dos horários de aula e Jandira ficava apreciando-os e tecendo comentários sobre eles. Ela buscava nos 
desenhos dos alunos a marca individual de cada um, "a revelação do indivíduo enquanto criador".

Um fato interessante, e até engraçado, relatado por Jandira, era o que acontecia nas aulas de desenho de modelo vivo. Os próprios alunos eram modelos uns dos outros e alguns deles tinham vergonha, entâo toda a turma fazia coro, "tira, tira", pedindo que os alunos tirassem a roupa.

Jandira conta que dava aulas no período matutino e vespertino, e na hora do almoço ficava com o professor Luis Carlos Canabarro Machado, conhecido como Canabarro, fazendo trabalhos de cerâmica, assim aproveitavam o horário do almoço para produzir arte. Com o professor Geraldo, Jandira produziu muitas gravuras, solicitadas pela própria UDESC para fazer parte dos calendários que eram distribuídos no final do ano.

Aposentada, Jandira dedica-se ainda mais ao desenho. Comenta que ao se aposentar teve "um pouco de dor na alma, porque estava a todo gás". Dedica-se a tarefas do cotidiano, aos cuidados com a sua mãe, que na época tinha 90 anos, e à Arte. Mais sua maior dedicação é ao desenho. Para Jandira o desenho é "uma segunda pele, estou sempre precisando desenhar, pouquinho como urso, uma hora dou uma paradinha, parece que fica fermentando lá dentro das ideias, e daqui a pouco tenho que desenhar de novo".

Jandira se diz contemplativa para o desenho. Fica olhando o espaço e depois desenha. Não gostava muito de escrever e comenta que escreveu poucos textos, apenas os que eram solicitados pela universidade. Jandira pensa não ter facilidade para a escrita "eu reescrevo este parágrafo umas trezentas vezes". Para ela o texto "vai vindo numa nebuloooosa, depois a nebulosa vai chegando mais peeeerto, não tenho esse talento assim, nunca me dediquei especificamente". Em contrapartida, gosta muito de ler, mesmo aposentada, continua suas leituras para ficar atualizada sobre as publicaçóes de arte.

\section{CEART, ontem e hoje}

Чoje, Jandira já não vai ao Centro de Artes com frequência. O que 1 sabe sobre ele é o que seus colegas lhe contam. Os professores são outros, mas muitos deles foram seus ex-alunos, o que lhe deixa muito orgulhosa. 
Jandira comenta sobre os professores da sua época que eram apaixonados pela arte. E dá um exemplo:

Como a professora Doraci, que era muito apaixonada pelo que ela fazia, ela criava pastéis, lá, ela criava lápis, ela criava papéis, pastéis e papéis, então, havia aquela paixão muito grande pelo produzir, pelo crescimento da compreensão da pessoa, por que eu escolhi arte, o que que eu quero com arte, porque arte é importante na vida, na minha vida, no meu contexto, esse viver arte mais intensamente, viver, vivenciar, a arte, falar sobre arte.

O fazer e vivenciar arte eram a grande preocupação dos professores, Jandira comenta que ela e seus colegas aproveitavam os momentos juntos para conversar sobre arte.

Para Jandira, o CEART foi o segundo emprego da sua vida, onde teve o privilégio de ser convidada para trabalhar, e em suas palavras ele representou

Pelo menos três coisas, importantes: um a tranquilidade de ter um emprego, que considero uma coisa banal, mas em todo o caso é um emprego; segundo cresci, como artista, passei a conhecer mais profundamente a arte, eu fui sofisticando a minha paixão pela arte; e, terceiro, participei da formação de pessoas que também amam e amavam a arte e que também continuaram, igual a um facho levando adiante, e entáo foi uma experiência maravilhosa, da qual eu só guardo boas lembranças.

Jandira comenta como aspecto negativo as reunióes de departamento, onde alguns colegas ficavam fazendo reclamaçóes sobre assuntos que não eram pertinentes ao momento e nem ao CEART, isso fazia com que os assuntos propriamente ditos da reuniáo demorassem a ser abordados. Jandira acreditava que o tempo da reunião não era o momento para assuntos alheios a Arte e as questóes não relacionadas com o CEART, por isso se sentia incomodada, e acabou relatando isto como o único ponto negativo da sua passagem pelo CEART como professora.

De maneira geral, dentro do CEART, Jandira teve muitos momentos de confraternização com seus colegas e de muito trabalho também, "foi uma experiência linda, guardo boas lembranças". 


\section{Referências}

BORTUCAN, Vanessa. Jandira Lorenz: O mundo como desenho. Trabalho de Conclusão de Curso. Universidade do Estado de Santa Catarina (UDESC). Florianópolis, 2012. Acesso em 10/10/2014. Disponível em: http://www.pergamum.udesc.br/dadosbu/000000/000000000015/000015F2.pdf

BUENO, Francisco da Silveira. Minidicionário da Lingua Portuguesa. São Paulo: FTD, 1996.

KUERTEN, Fernanda. UDESC 40 anos. Florianópolis: Udesc, 2005.

MARCONI, Marina de Andrade; LAKATOS, Eva Maria. Técnicas de pesquisa. $7^{0}$ edição. São Paulo: Atlas, 2010.

NÓVOA, António. Para uma formação de professores construída dentro da profissão. In: Professores Imagens do futuro presente. (p. 10 a 18). Lisboa 2009.

PENNA, Maura. Música(s) e seu ensino. $2^{\circ}$ ed. Porto Alegre: Sulina, 2012

NÓVOA, António. Professores: Imagens do futuro presente. Lisboa: Educa, 2009. 